\title{
Influence of vitamins $C$ and $E$ on the quality of cryopreserved semen Prochilodus brevis (Prochilodontidae, Teleostei)
}

\section{Influência das vitaminas $\mathrm{C}$ e $\mathrm{E}$ sobre a qualidade do semen criopreservado de Prochilodus brevis (Prochilodontidae, Teleostei)}

\author{
Priscila Silva de Almeida-Monteiro ${ }^{1 *}$; Mayara Setúbal Oliveira-Araújo ${ }^{1}$; Romulo \\ Roberto Ribeiro Pinheiro'; Júlia Trugilio Lopes ${ }^{1}$; Yasmim Maia Ferreira ${ }^{2}$; Assis \\ Rubens Montenegro ${ }^{3}$; Mônica Aline Parente Melo-Maciel'; Carminda Sandra Brito \\ Salmito-Vanderley ${ }^{4}$
}

\begin{abstract}
Seminal cryopreservation allows the long-term conservation of gametes of various species, including endangered species, such as Prochilodus brevis. However, the application of this biotechnology can cause damage to sperm cells, reducing seminal quality. Thus, we have sought substances that minimize the damage caused by this process, such as antioxidants. Thus, this study aimed to evaluate the association between two cryoprotectants and two vitamins, in different concentrations, on the quality of cryopreserved semen of $P$. brevis. For cryopreservation, the experiment was performed in two stages. In the first stage, the semen of 10 animals was submitted to six different freezing means, coming from the combination of $5 \%$ glucose, two cryoprotectants (Dimethyl sulfoxide [DMSO] or Methyl glycol) and two vitamins ( $\mathrm{C}$ or $\mathrm{E}$ to $0.0001 \mathrm{mg}$ ) for cryopreservation. In the second stage, semen samples of eight animals were diluted in 5\% glucose and the best cryoprotectant found in the first stage, associated with three different concentrations of vitamins C or E $(0.01,0.001$, and $0.0001 \mathrm{mg})$. In both steps, the in natura and post-thawed samples were submitted to kinetic analysis, morphology, and sperm membrane integrity. The cryopreserved semen with DMSO presented significantly higher results $(\mathrm{p}<$ 0.05 ) than that frozen with Methyl glycol, regardless of the vitamin used. The morphologically normal spermatozoa rate was higher $(\mathrm{p}<0.05)$ in the vitamin-containing samples, however, vitamin E reduced sperm motility rates, independent of the cryoprotectant used. As for vitamin concentrations, higher motility rates were obtained when cryopreserved semen with 0.01 and $0.0001 \mathrm{mg}$ of any of the vitamins. However, the higher concentration had a deleterious effect on the spermatic morphology of P. brevis. Therefore, the glucose associated with DMSO and the lower concentration of vitamin C provides good quality for the post-thawed semen of $P$. brevis.
\end{abstract}

Key words: Antioxidants. Cryopreservation of semen. Common curimatã. Fish.

1 Discentes, Curso de Doutorado, Programa de Pós-Graduação em Ciências Veterinárias, Universidade Estadual do Ceará, UECE, Fortaleza, CE, Brasil. E-mail: priscilla_vs@hotmail.com; maysetubal31@gmail.com; juliatrugilio@gmail.com

2 Discentes, Curso de Graduação em Ciências Biológicas, UECE, CE, Brasil. E-mail: romuloroberto_bio@hotmail.com; yasmim. maia@ymail.com.br

3 Discente, Curso de Doutorado, Programa de Doutorado Integrado em Zootecnia, UFC, Fortaleza, CE, Brasil. E-mail: assismontenegro@yahoo.com.br

$4 \operatorname{Prof}^{\text {as }}$ Dr $^{\text {as }}$, Curso de Ciências Biológicas, UECE, Fortaleza, CE, Brasil. E-mail: monicaaline3@hotmail.com; sandra.salmito@ uece.br

* Author for correspondence 


\section{Resumo}

A criopreservação seminal permite a conservação em longo prazo dos gametas de diversas espécies, inclusive as ameaçadas, como a Prochilodus brevis. Contudo, a aplicação dessa biotecnologia pode causar danos às células espermáticas, reduzindo a qualidade seminal. Assim, tem-se buscado substâncias que minimizem os danos causados por esse processo, como os antioxidantes. Deste modo, este estudo objetivou avaliar a associação entre dois crioprotetores e duas vitaminas, em diferentes concentrações, sobre a qualidade do sêmen criopreservado de $P$. brevis. Para a criopreservação, o experimento foi realizado em duas etapas. Na primeira, o sêmen de 10 animais foi submetido a seis diferentes meios de congelação, oriundos da combinação de glicose 5\%, dois crioprotetores (Dimetilsulfóxido [DMSO] ou Metilglicol) e duas vitaminas (C ou E a 0,0001 mg), para a criopreservação. Na segunda etapa, amostras de sêmen de oito animais foram diluídas em Glicose 5\% e DMSO (melhor crioprotetor encontrado na primeira etapa), associados a três diferentes concentrações das vitaminas $\mathrm{C}$ ou $\mathrm{E}(0,01 ; 0,001 \mathrm{e}$ $0,0001 \mathrm{mg}$ ). Em ambas as etapas, as amostras in natura e pós-descongeladas foram submetidas às análises de cinética, morfologia e integridade de membrana espermática. O sêmen criopreservado com DMSO apresentou resultados significativamente superiores $(\mathrm{p}<0,05)$ comparado ao congelado com Metilglicol, independente da vitamina utilizada. A taxa de espermatozoides morfologicamente normais foi superior $(\mathrm{p}<0,05)$ nas amostras contendo vitamina, contudo a vitamina $\mathrm{E}$ reduziu as taxas de motilidade espermática, independente do crioprotetor utilizado. Quanto às concentrações das vitaminas, obtiveram-se maiores taxas de motilidade quando se criopreservou sêmen com 0,01 e 0,0001 mg de qualquer uma das vitaminas. Entretanto, a maior concentração teve efeito deletério sobre a morfologia espermática de $P$. brevis. Portanto, a glicose associada ao DMSO e à menor concentração de vitamina $\mathrm{C}$ proporciona boa qualidade ao sêmen pós-descongelado de $P$. brevis.

Palavras-chave: Antioxidantes. Criopreservação seminal. Curimatã comum. Peixe.

\section{Introduction}

Semen cryopreservation consists of the conservation of gametes in the long term by means of freezing in liquid nitrogen, with the advantages of synchronizing the availability of the male and female gametes, conserving the genetic variability, reducing the maintenance costs of the breeding stock, and allowing genetic material exchanges between laboratories and fish farms, among others (GODINHO, 2007). It is a technique developed for both environmental and economic issues, since the use and implantation of genetic banks, including semen freezing, are potential solutions to minimize losses due to anthropic actions on native fish. Thus, cryopreservation can be used as a tool to guarantee genetic diversity, both for repopulation programs and for commercial production (SHIMODA, 2004), allowing the conservation of species, such as Prochilodus brevis, Steindachner, 1875.

Known regionally as common curimatã, this species is rheophilic, belonging to the order of
Characiformes, native to the northeast region and endemic in the states of Piauí, Ceará, and Rio Grande do Norte, and can also be found in the southeast of the country (DOURADO, 1981; ARAÚJO; GURGEL, 2002). Besides the economic importance to the region, mainly by the appreciation of its ova, the curimatã has a strong social appeal because its consumption is linked to subsistence; and ecological, due to their iliophage habit when adult (NUNES et al., 2016; DOURADO, 1981), since they recycle the organic matter of the rivers, supporting the upper trophic levels (MOORE et al., 2004).

There are few studies on cryopreservation for this species (LOPES et al., 2014; NUNES et al., 2016; PINHEIRO et al., 2016), showing some possibilities for the application of this biotechnology. However, the application of this technique constitutes a stressful event on the sperm cells, and can stimulate the formation of reactive oxygen species (ROS), which determines a reduction of the structural 
and functional integrity of spermatozoa (SILVA, GUERRA, 2012). In this way, it is necessary to test solutions that minimize the damage caused during this process.

In order to enhance the protection of the sperm cell, it is possible to make use of antioxidants, compounds that combat ROS (MANEESH; JAYALEKSHMI, 2006; SIKKA, 1996, 2004). Fish semen has natural antioxidants, both inside and outside the cells, but there is great cytoplasmic loss during spermatogenesis, which leaves the spermatozoa basically dependent on the antioxidants of the seminal plasma. In addition, cryopreservation reduces plasma antioxidant concentrations, due to the dilution of the semen (GUERRA et al., 2004; SARLÓS et al., 2002; WATSON, 2000). Thus, it is necessary to add substances that overcome this lack, since the imbalance between antioxidant and oxidative substances results in toxic effects and impairment of cellular functionality, which leads to apoptosis and the reduction of sperm fertility (PURDY, 2006; STORNELLI et al., 2005).

Thus, the use of antioxidant substances, such as vitamin $\mathrm{C}$ (ascorbic acid) and vitamin $\mathrm{E}$ ( $\alpha$-tocopherol), as a supplement to freezing media can neutralize the effects of ROS, thus ensuring the viability of sperm cells after thawing (MICHAEL et al., 2007).

A number of studies have shown that these vitamins are used for seminal cryopreservation of Characiform fish (PAULA et al., 2012; NAVARRO et al., 2014), and there are no reports of their use for common curimatan seminal diluents. The objective of this study is to evaluate the association between two cryoprotectants and vitamins $\mathrm{C}$ and $\mathrm{E}$, in different concentrations, on the quality of the cryopreserved semen of Prochilodus brevis.

\section{Material and Methods}

The study was approved by the Animal Ethics Committee of the State University of Ceará
(4306061/2015). The experiments were carried out between May and August 2015, at the Laboratory of Biotechnology of Fish Reproduction (LBRP) ( $3^{\circ}$ 47’36.2 “S; $\left.38^{\circ} 33^{\prime} 30.1^{\prime \prime} \mathrm{W}\right)$ of the State University of Ceará (UECE), Fortaleza, Ceará, Brazil.

The animals were kept in 7100 liter fiberglass tanks with constant aeration and fed daily with commercial feed containing 32\% crude protein supplied at a rate of $3 \%$ live weight, divided into two meals per day. Twenty males of common curimatã (weight: $155.78 \pm 12.64$ g, length: $20.76 \pm 0.41$ $\mathrm{cm})$ were hormonally induced to sperm through a single dose ( $3 \mathrm{mg} \mathrm{kg}^{-1}$ body weight) of pituitary extract of carp (EPC), applied intracelomatically at the base of the pectoral fin. After 14 hours, each animal was sedated with clove oil-based solution (Eugenol; União Vegetal Suplementos Nutricionais Ltda.), in the proportion of 1:10:10000 (eugenol: alcohol: water, resulting in a final concentration of $1 \times 10^{-5} \mathrm{ml}$ eugenol), and the semen was collected in graduated polyethylene tubes and kept in a thermal box at $4{ }^{\circ} \mathrm{C}$ until the samples were processed.

The in natura semen was evaluated for $\mathrm{pH}$ using measuring tapes (MERCK, Germany) for the sperm concentration in a Neubauer chamber, and the volume, by means of the graduation of the collection tubes. Then, individual aliquots were assigned to the following sperm analyses: morphology, membrane integrity, and kinetics.

For the analysis of sperm morphology, the semen was fixed in 4\% formolized citrate solution (1:100; semen: fixative) and then stained with Rose Bengal in the ratio of 3:20 (dye: fixed semen). Two slides were prepared per animal, of which 100 cells per slide were evaluated with the aid of an optical microscope (400x). The classification of spermatozoa was performed according to Nunes et al. (2016).

The sperm membrane integrity, or sperm vitality, was evaluated by the eosin-nigrosin staining method, and a slide was prepared per animal in the proportion 1:10:10 (semen: eosin: nigrosin). Using 
a light microscope (400x), 200 spermatozoa per slide were analyzed and considered with the whole membrane, when they were colorless or with a ruptured membrane when stained pink or red.

In order to evaluate the kinetics, a computer assisted sperm analysis (CASA) system was used, using Sperm Class Analyzer (SCA, Microptics, Barcelona, Spain, version 3.2) configured for fish. To do this, $1 \mu \mathrm{L}$ of the semen in natura was deposited in a Makler chamber and activated with $100 \mu \mathrm{L}$ of $50 \mathrm{mM} \mathrm{NaCl}\left(100 \mathrm{mOsm} \mathrm{kg}{ }^{-1}\right)$. The parameters evaluated were: total motility (\%), curvilinear velocity (VCL, $\mu \mathrm{m} \mathrm{s}^{-1}$ ), straight-line velocity (VSL, $\mu \mathrm{m} \mathrm{s}^{-1}$ ) and mean velocity of the course (VAP, $\mu \mathrm{m}$ $\mathrm{s}^{-1}$ ), at least 1000 sperm per analysis.

The cryopreservation procedures were performed in two stages. In the first step, uncontaminated samples $(\mathrm{n}=10)$ with motility higher than $90 \%$ after activation were selected for the experiment.

Each semen sample was diluted (1:9, semen: cryodilution solution) in 5\% glucose, combined with the cryoprotectants $10 \%$ DMSO or $10 \%$ Methyl glycol (Vetec Química Fina Ltda., Rio de Janeiro, Brazil) and combined or not with two antioxidants (Vitamin $\mathrm{C}$ or Vitamin E, Farmafótmula $^{\circledR}$ Manipulation Pharmacy, Ceará, Brazil) at a concentration of $0.0001 \mathrm{mg}$.

After dilution, the samples were submitted to the cryopreservation process. For this, each treatment was packed in two $0.25 \mathrm{~mL}$ French straws, sealed with polyvinyl alcohol and kept in racks under refrigeration $\left(\sim 10{ }^{\circ} \mathrm{C}\right)$ for 10 minutes for the equilibration time. The vanes were then frozen in a dry shipper $\left(-176^{\circ} \mathrm{C}\right)$ for 15 minutes and transferred to a liquid nitrogen canister at $-196^{\circ} \mathrm{C}$. After 15 days, the samples were thawed in a water bath at $30^{\circ} \mathrm{C}$ for 16 seconds (NUNES et al., 2016) and analyzed for sperm kinetics, morphology, and membrane integrity, following the same methodology for semen in natura.

From the results obtained in the first stage and in order to evaluate the effectiveness of different concentrations of these antioxidants, the second stage was started, in which samples $(n=8)$ were selected without contamination and with motility higher than $90 \%$ for cryopreservation. In natura semen was diluted (1:9, semen: diluent) in medium containing 5\% glucose and the best cryoprotectant found in the first stage associated with vitamins $\mathrm{C}$ or $\mathrm{E}$ in three different concentrations $(0.01 \mathrm{mg}, 0.001$ $\mathrm{mg}$, or $0.0001 \mathrm{mg}$ ).

After dilution, the samples were cryopreserved, thawed and analyzed, as described in step 1.

\section{Statistical analysis}

Data were initially submitted to the Shapiro-Wilk and Bartlett tests for normal residue distribution and homoscedasticity, respectively. ANOVA was performed using the GLM procedure of the SAS program, 2002, considering a completely randomized design, in a $2 \times 3$ factorial arrangement, represented by the cryoprotectant effect (DMSO and Methyl glycol) and the effect of vitamins (C and E). The variables that did not present the assumptions for performing the analysis of variance underwent logarithmic transformation. There was no significant interaction for any variable. When a significant effect was observed, comparisons between treatments were made using either the F-test (cryoprotectant effect) or the StudentNewman-Keuls test (effect of vitamins). Results were presented as mean \pm standard error. Differences were considered significant when $\mathrm{p}<0.05$.

\section{Results and Discussion}

The semen collected from all the animals $(0.72$ $\pm 0.06 \mathrm{~mL}, \mathrm{pH}: 8.54 \pm 0.05)$ had $97.19 \pm 0.67 \%$ of spermatozoa with intact membrane and 66.17 $\pm 1.76 \%$ with normal morphology. The sperm concentration was $32.97 \times 10^{9} \pm 8.44$ spermatozoa per $\mathrm{mL}$ of semen. The total motility rate was $97.34 \pm$ $1.87 \%$, and mean values of VCL, VSL, and VAP of $113.51 \pm 18.3 \mu \mathrm{m} \mathrm{s}^{-1}$ were found; $44.29 \pm 7.39 \mu \mathrm{m}$ 
$\mathrm{s}^{-1}$ and $86.07 \pm 15.56 \mu \mathrm{m} \mathrm{s}^{-1}$, respectively.

It is essential to know the characteristics of the semen in natura of a species, since this factor can influence seminal quality after cryopreservation (SOLIS-MURGAS et al., 2011). The seminal volume and sperm concentration and morphology data obtained in this study were similar to those found for the same species by Nunes et al. (2016); $\left(0.56 \pm 0.24 \mathrm{~mL}, 27.89 \pm 6.13 \mathrm{sptz} \mathrm{mL}^{-1}\right.$ and 74.18 $\pm 10.63 \%$, respectively), but differed from the values reported by Lopes et al. (2014); (1.31 \pm 0.64 $\mathrm{mL}, 22.26 \pm 9.34 \mathrm{sptz} \mathrm{mL}^{-1}$ and $97.21 \pm 1.46 \%$, respectively). According to Solis-Murgas et al. (2011), these characteristics can be influenced by several factors, such as nutritional status, age, and weight of animals, health status, type, and dosage of the hormone used for induction, climate, time of year, and frequency of collection, among other aspects. In relation to $\mathrm{pH}$ and sperm kinetics data (total motility, VCL, VSL and VAP), the values obtained in the present study were similar to those found by Lopes et al. (2014) and Nunes et al. (2016).

As for the first step, there was no interaction between cryoprotectants (DMSO or Methyl glycol) and vitamins (C or E). In relation to the cryoprotectants, a significant difference was found among them, so that for all analyzed parameters (spermatic kinetics, membrane integrity, and morphologically normal spermatozoa), the cryopreserved samples with DMSO were superior $(p<0.05)$ to those with Methyl glycol, regardless of whether or not the vitamins are used (Table 1).

Table 1. Mean \pm standard error of the sperm parameters of semen of Prochilodus brevis cryopreserved with Dimethyl sulfoxide (DMSO) and Methyl glycol (MG) regardless of the use of vitamins (C or E).

\begin{tabular}{lcc}
\hline Parâmetros & DMSO & MG \\
\hline Motilidade total (\%) & $38.22 \pm 2.15^{\mathrm{a}}$ & $16.60 \pm 1.26^{\mathrm{b}}$ \\
VCL & $57.34 \pm 1.75^{\mathrm{a}}$ & $49.55 \pm 2.05^{\mathrm{b}}$ \\
VSL & $34.61 \pm 2.24^{\mathrm{a}}$ & $20.26 \pm 1.59^{\mathrm{b}}$ \\
VAP & $48.37 \pm 2.26^{\mathrm{a}}$ & $33.88 \pm 1.79^{\mathrm{b}}$ \\
Normal (\%) & $59.17 \pm 1.78^{\mathrm{a}}$ & $48.28 \pm 2.51^{\mathrm{b}}$ \\
Cauda dobrada (\%) & $38.74 \pm 1.87^{\mathrm{b}}$ & $44.83 \pm 2.01^{\mathrm{a}}$ \\
Membrana íntegra & $63.08 \pm 1.92^{\mathrm{a}}$ & $55.44 \pm 2.31^{\mathrm{b}}$ \\
\hline
\end{tabular}

Different lowercase letters on the same line indicate difference between cryoprotectors.

DMSO, as well as most cryoprotectants, is a substance toxic to cells; however, it is considered the best cryoprotectant for semen of freshwater fish (SALMITO-VANDERLEY et al., 2012), being in agreement with the results found for several species of freshwater fish, such as Colossoma macropomum (OLIVEIRA et al., 2016), P. lineatus (NASCIMENTO et al., 2012), and P. magdalenae (MARTÍNEZ et al., 2012), including P. brevis as reported by Nunes et al. (2016). Despite the toxicity, the use of cryoprotectants for the freezing of semen is indispensable, since the reduction of temperature during the process leads to the formation of ice crystals, which can damage the plasma membrane of sperm cells (SALMITO-VANDERLEY et al., 2012).

The reduction of the parameters analyzed when using Methyl glycol may be related to a greater sensitivity of the spermatozoa of this species to this cryoprotectant, since the action of the cryoprotectants is species-specific and it is necessary to test the different substances available 
for each species (PEÑARANDA et al., 2009).

Regarding the use of vitamins, in the present study, the addition of vitamin $\mathrm{E}$ to the freezing medium led to a decrease in the motility rate (Table 2), as observed by Liu et al. (2015) for Pagrus major. However, this vitamin did not influence the sperm motility rates of $P$. lineatus (NAVARRO et al., 2014), S. aurata or D. labrax (CABRITA et al., 2011; MARTÍNEZ-PÁRAMO et al., 2012). These results differ from those found for human semen (ASKARI et al., 1994) and boar (PENA et al., 2003), suggesting that this vitamin is more effective for mammals than for fish. In addition, the performance of vitamin $\mathrm{E}$ is influenced by storage conditions, lipid composition of sperm membranes, and antioxidant concentrations in the semen of different species (BALL; VO, 2002), emphasizing the differences in both the structural characteristics of the cell and in the internal antioxidant system of each species.

Table 2. Mean \pm standard error of the sperm parameters of the cryopreserved Prochilodus brevis semen in the absence or presence of vitamins $\mathrm{C}$ or $\mathrm{E}$, independent of the cryoprotectant used (DMSO or MG).

\begin{tabular}{lccc}
\hline Parâmetros & - & C & E \\
\hline Motilidade total (\%) & $29.69 \pm 3.07^{\mathrm{a}}$ & $26.29 \pm 4.13^{\mathrm{ab}}$ & $23.72 \pm 2.86^{\mathrm{b}}$ \\
VCL & $52.69 \pm 2.74^{\mathrm{a}}$ & $53.89 \pm 3.09^{\mathrm{a}}$ & $52.95 \pm 1.85^{\mathrm{a}}$ \\
VSL & $27.64 \pm 2.74^{\mathrm{a}}$ & $26.43 \pm 3.82^{\mathrm{a}}$ & $26.53 \pm 2.25^{\mathrm{a}}$ \\
VAP & $39.87 \pm 2.88^{\mathrm{a}}$ & $40.97 \pm 3.99^{\mathrm{a}}$ & $40.90 \pm 2.28^{\mathrm{a}}$ \\
Normal (\%) & $42.47 \pm 3.26^{\mathrm{b}}$ & $55.50 \pm 2.51^{\mathrm{a}}$ & $60.47 \pm 1.62^{\mathrm{a}}$ \\
Cauda dobrada (\%) & $49.79 \pm 3.26^{\mathrm{a}}$ & $40.42 \pm 2.17^{\mathrm{b}}$ & $36.78 \pm 1.26^{\mathrm{b}}$ \\
Membrana íntegra & $58.42 \pm 2.99^{\mathrm{a}}$ & $61.78 \pm 2.45^{\mathrm{a}}$ & $58.86 \pm 2.71^{\mathrm{a}}$ \\
\hline
\end{tabular}

Different lowercase letters on the same line indicate difference between the use of vitamins or not.

No significant difference $(\mathrm{p}>0.05)$ was observed in relation to VCL, VSL, and VAP when these vitamins were used (Table 2). This is the first study investigating the action of antioxidant substances on these parameters in the cryopreserved semen of Characiform fish. The results found in this study indicate that oxidative stress has no influence on sperm velocity.

As for membrane integrity, a greater than 58\% rate of intact membrane spermatozoa was found in all samples, whereas Nunes et al. (2016) observed $41.61 \pm 3.05 \%$ intact cells (Tables 1 and 2). However, no significant differences $(\mathrm{p}>0.05)$ were found between the cryopreserved samples with and without vitamins. This parameter does not seem to be related to oxidative stress, since the addition of these antioxidant substances (vitamins $\mathrm{C}$ and $\mathrm{E}$ ) to the semen of P. brevis did not improve the integrity of the sperm membrane. A similar result was observed by Martínez-Páramo et al. (2012) when working with the semen of D. labrax.

This study is also a pioneer in reporting data on the morphology of spermatozoa of Characiform fish, using additional antioxidant substances to the freezing media. The normal sperm count was higher $(\mathrm{p}<0.05)$ when the semen was cryopreserved with both vitamin $\mathrm{C}$ and vitamin $\mathrm{E}$ compared to that without vitamins (Table 2). Among the morphopathologies, the most commonly found was the folded tail, being observed in a larger quantity in the cryopreserved semen without vitamins.

The pathologies found may be related to the ultrastructural changes in the spermatozoa due to changes in the osmolarity of the environment that 
surrounds them during the cryopreservation process (MARQUES, 2001). These changes may also be related to lipid peroxidation, which consists of the oxidative degradation of the polyunsaturated fatty acids of the phospholipids of the plasma membrane by ROS, modifying the structure and permeability of cell membranes (MELLO-FILHO et al., 1983). Vitamin E, because it is liposoluble, protects the cell against lipoperoxidation directly in the plasma membrane, acting as a chelator of the ROS produced during this process; and besides suppressing the production of malondialdehyde, it one of the major indicators of oxidative stress (AITKEN; CLARKSON, 1988; FERREIRA; MATSUBARA, 1997). However, vitamin $C$ acts on the membranes in an aqueous medium, both directly and indirectly, acting efficiently on the major ROS produced during lipid peroxidation (VASCONCELOS et al., 2007).

There were no interactions between the vitamins (C or $\mathrm{E}$ ) and the concentrations used (0.01, 0.001, $0.0001 \mathrm{mg}$ ) when the P. brevis semen was cryopreserved with glucose $5 \%$ and $10 \%$ DMSO. No significant differences were found between vitamin $\mathrm{C}$ and $\mathrm{E}$ for any of the parameters evaluated in this second stage, regardless of vitamin concentration (Table 3). Similar results were found by Cabrita et al. (2001) and Navarro et al. (2014) when using these same vitamins for the seminal cryopreservation of $S$. aurata and D. labrax, and $P$. lineatus, respectively.

Table 3. Mean \pm standard error of the sperm parameters of Prochilodus brevis semen cryopreserved with glucose and DMSO supplemented with vitamins $C$ or E, regardless of the concentration used $(0.01,0.001$, or $0.0001 \mathrm{mg})$.

\begin{tabular}{lcc}
\hline Parâmetros & C & E \\
\hline Motilidade total (\%) & $67.70 \pm 1.52$ & $70.06 \pm 1.70$ \\
VCL & $50.87 \pm 1.25$ & $53.17 \pm 0.86$ \\
VSL & $37.53 \pm 1.10$ & $37.43 \pm 0.84$ \\
VAP & $47.34 \pm 1.23$ & $49.10 \pm 0.93$ \\
Normal (\%) & $55.77 \pm 1.60$ & $57.19 \pm 1.92$ \\
Cauda dobrada (\%) & $42.69 \pm 1.53$ & $41.71 \pm 1.83$ \\
Membrana íntegra & $88.26 \pm 1.71$ & $87.00 \pm 1.11$ \\
\hline
\end{tabular}
$\mathrm{p}>0,05$

Regarding the concentrations employed, regardless of the vitamin used (Table 4), there was no significant difference in relation to sperm velocity and membrane integrity. However, the motility rate was higher $(p<0.05)$ when the concentrations of $0.01 \mathrm{mg}$ and $0.0001 \mathrm{mg}$ of any of the vitamins were used. 
Table 4. Mean \pm standard error of sperm parameters of Prochilodus brevis semen cryopreserved with glucose and DMSO supplemented with different concentrations of vitamins $\mathrm{C}$ or $\mathrm{E}$, regardless of the vitamin used.

\begin{tabular}{lccc}
\hline Parâmetros & $\mathbf{0 , 0 1}$ & $\mathbf{0 , 0 0 1}$ & $\mathbf{0 , 0 0 0 1}$ \\
\hline Motilidade total (\%) & $72.46 \pm 1.62^{\mathrm{a}}$ & $64.16 \pm 1.72^{\mathrm{b}}$ & $70.02 \pm 2.05^{\mathrm{a}}$ \\
VCL & $50.48 \pm 0.92^{\mathrm{a}}$ & $52.09 \pm 1.47^{\mathrm{a}}$ & $53.46 \pm 1.44^{\mathrm{a}}$ \\
VSL & $36.57 \pm 1.18^{\mathrm{a}}$ & $37.69 \pm 1.22^{\mathrm{a}}$ & $38.19 \pm 1.19^{\mathrm{a}}$ \\
VAP & $46.61 \pm 1.06^{\mathrm{a}}$ & $48.34 \pm 1.50^{\mathrm{a}}$ & $49.67 \pm 1.34^{\mathrm{a}}$ \\
Normal (\%) & $52.31 \pm 2.36^{\mathrm{b}}$ & $59.94 \pm 1.79^{\mathrm{a}}$ & $57.19 \pm 1.93^{\mathrm{ab}}$ \\
Cauda dobrada (\%) & $45.75 \pm 2.22^{\mathrm{a}}$ & $39.34 \pm 1.81^{\mathrm{a}}$ & $41.50 \pm 1.88^{\mathrm{a}}$ \\
Membrana íntegra & $87.60 \pm 1.58^{\mathrm{a}}$ & $86.94 \pm 2.04^{\mathrm{a}}$ & $88.31 \pm 1.62^{\mathrm{a}}$ \\
\hline
\end{tabular}

Different lowercase letters on the same line indicate difference between the different concentrations of vitamins $\mathrm{C}$ and E, independent of vitamin.

Navarro et al. (2014) found no difference between vitamins $\mathrm{C}$ and $\mathrm{E}$ on the motility rate of $P$. lineatus when they used the concentration of 0.0001 mg. The same was observed by Cabrita et al. (2011), who used concentrations of 1 and $10 \mathrm{mM}$ of vitamin $\mathrm{C}$ and 0.1 and $0.5 \mathrm{mM}$ of vitamin E for S. aurata. On the other hand, Martínez-Páramo et al. (2012) found an improvement in the sperm motility rate of D. labrax when they supplemented freezing media with $0.1 \mathrm{mM}$ of these vitamins. Likewise, Ubilla and Valdebenito (2011) demonstrated that the addition of $0.018 \mathrm{mg} \mathrm{mL}^{-1}$ of vitamin $\mathrm{C}$ to the diluent medium improved the sperm motility and fertilization rates of Oncorhynchus mikiss. This emphasizes that the use of antioxidants, besides being specific for each species, is dependent on the dosage used.

A similar situation was observed regarding sperm morphology; the highest rate of morphologically normal spermatozoa was found when the semen was cryopreserved with the two lowest concentrations (0.001 $\mathrm{mg}$ and $0.0001 \mathrm{mg}$; Table 4), independent of the vitamin used. This result can be explained by a possible toxic effect of the highest concentration employed.

According to Carvalho et al. (2002), the use of antioxidant substances may present undesirable effects if the safety dose is exceeded, since they may inhibit the physiological functions performed by ROS in mammalian spermatozoa, such as hyperactivation, capacitation, and acrosome reaction. However, it is not yet known what functions the EROs exert on the spermatozoa of fish of external fertilization, such as $P$. brevis.

Although the higher concentration of vitamins negatively affected the sperm morphology, the same did not occur for the motility rate. Some defects in sperm morphology do not totally impede sperm motility, since there are more serious pathologies that can negatively affect motility rates and, consequently, fertilization rates (MILIORINI et al., 2011). In addition, in the present study, the most commonly found defect was that of a folded tail, a pathology that, according to the same author, is one that affects fertilization rates less.

This was the first study that used antioxidant substances in the seminal diluents for the cryopreservation of $P$. brevis semen. In view of the satisfactory results found, the study has created prospects for new investigations that evaluate both the association of both antioxidants used in the present research, other concentrations of these vitamins, as well as the use of other substances with the same properties. 


\section{Conclusions}

The use of vitamins $\mathrm{C}$ and $\mathrm{E}$ has a different effect on the different quality parameters of the cryopreserved semen of $P$. brevis, depending on the form that these antioxidants are used in the cryopreservation protocols. According to the results obtained in steps 1 and 2, the addition of vitamin $\mathrm{C}$ at a concentration of $0.0001 \mathrm{mg}$ to the freezing medium containing $10 \%$ DMSO and $5 \%$ Glucose is suggested, since this provided a greater uniformity between the evaluated parameters, mainly for morphopathology.

\section{Acknowledgements}

The authors would like to acknowledge the National Council for Scientific and Technological Development $(\mathrm{CNPq})$ and the Financier of Studies and Projects (FINEP).

\section{References}

AITKEN, R. J.; CLARKSON, J. S. Significance of reactive oxygen species and antioxidants in defining the efficacy of sperm preparation techniques. Journal of Andrology, Malden, v. 6, n. 6, p. 367-376, 1988.

ARAúJO, S. A.; GURGEL, H. C. B. Aspectos da biologia de Prochilodus cearenses (Steindachner, 1911) (Characiformes, Prochilodontidae) no açude Itans/Caicó, Rio Grande do Norte. Revista Brasileira de Zoociências, Juiz de Fora, v. 4, n. 1, p. 85-96, 2002.

ASKARI, H. Á.; CHECK, J. H.; PEYMER, N.; BOLLENDORF, A. Effect of natural antioxidants tocopherol and ascorbic acids in maintenance of sperm activity during freeze-thaw process. Systems Biology in Reproductive Medicine, Londres, v. 33, n. 1, p. 11-15, 1994.

BALL, B. B.; VO, A. T. Detection of lipid peroxidation in equine spermatozoa based upon the lipophilic fluorescent dye C11-BODIPY581/591. Journal of Andrology, Malden, v. 23, n. 1, p. 259-269, 2002.

CABRITA, E.; MA, S.; DIOGO, P.; MARTÍNEZPÁRAMO, S.; SARASQUETE, C.; DINIS, M. T. The influence of certain aminoacids and vitamins on post-thaw fish sperm motility, viability and DNA fragmentation. Animal Reproduction Science, Amsterdam, v. 125, n. 1, p. 189-195, 2011.

CARVALHO, O. F.; FERREIRA, J. D. J.; SILVEIRA, N. A.; FRENEAU, G. E. Efeito oxidativo do óxido nítrico e infertilidade no macho. Jornal Brasileiro de Patologia e Medicina Laboratorial, Rio de Janeiro, v. 38, n. 1, p. 33-38, 2002.

DOURADO, O. F. Principais peixes e crustáceos dos açudes controlados pelo DNOCS. Fortaleza: Convênio SUDENE/DNOCS, $1981.40 \mathrm{p}$.

FERREIRA, A. L. A.; MATSUBARA, J. S. Radicais livres: conceitos, doenças relacionadas, sistema de defesa e estresse oxidativo. Revista da Associação Médica Brasileira, São Paulo, v. 43, n. 1, p. 61-68, 1997.

GODINHO, H. P. Estratégias reprodutivas de peixes aplicadas à aquicultura: bases para o desenvolvimento de tecnologias de produção. Revista Brasileira de Reprodução Animal, Belo Horizonte, v. 31, n. 1, p. 351360, 2007.

GUERRA, M. M. P.; EVANS, G.; MAXWELL, W. H. C. Papel de oxidantes e antioxidantes na andrologia: revisão de literatura. Revista Brasileira de Reprodução Animal, Belo Horizonte, v. 28, n. 1, p. 187-195, 2004.

LIU, Q.; WANG, X.; WANG, W.; ZHANG, X.; XU, S.; MA, D.; XIAO, Z.; XIAO, Y.; LI, J. Effect of the addition of six antioxidants on sperm motility, membrane integrity and mitochondrial function in red seabream (Pargus major) sperm cryopreservation. Fish Physiology and Biochemistry, Namur, v. 41, n. 1, p. 413-422, 2015.

LOPES, J. T.; PINHEIRO, J. P. S.; NUNES, L. T.; SOUZA, M. E. M.; ALMEIDA, P. S.; NASCIMENTO, R. V.; CAMPELLO, C. C.; SALMITO-VANDERLEY, C. S. B. Avaliação de diferentes crioprotetores e taxas de diluição na criopreservação seminal de Prochilodus brevis. Revista Brasileira de Reprodução Animal, Belo Horizonte, v. 38, n. 3, p. 170-175, 2014.

MANEESH, M.; JAYALEKSHMI, H. Role of reactive oxygen species and antioxidants on pathophysiology of male reproduction. Indian Journal of Clinical Biochemistry, Nova Delhi, v. 21, n. 2, p. 80-89, 2006.

MARQUES, S. Preservação a curto prazo do sêmen de teleósteos neotropicais de água doce. 2001. Dissertação (Mestrado em Zoologia de Vertebrados) - Pontifícia Universidade Católica de Minas Gerais, Belo Horizonte.

MARTÍNEZ, J. G.; TARAZONA-MORALES, A. M.; PARDO-CARRASCO, S. C. Sperm cryopreservation of freshwater fish bocachico (Prochilodus magdalenae) in DMSO and glucose and its effects on fertilization and hatching efficiency. Animal Reproduction, Belo Horizonte, v. 9, n. 1, p. 19-26, 2012. 
MARTÍNEZ-PÁRAMO, S.; DIOGO, P.; DINIS, M. T.; HERRÁEZ, M. P.; SARASQUETE, C.; CABRITA, E. Incorporation of ascorbic acid and $\alpha$-tocopherol to the extender media to enhance antioxidante system of cryopreserved sea bass sperm. Theriogenology, California, v. 77, n. 1, p. 1129-1136, 2012.

MELLO-FILHO, A. C.; HOFFMAN, M. E.; MENEGHINI, R. Cell killing and DNA damage by hydrogen peroxide are mediated by intracellular iron. Biochemical Journal, Londres, v. 218, n. 1, p. 273-275, 1984.

MICHAEL, A.; ALEXOPOUlOS, C.; PONTIKI, E.; HADJIPAVLOU-LITINA, D.; SARATSIS, P.; BOSCOS, C. Effect of antioxidant supplementation on semen quality and reactive oxygen species of frozen-thawed canine spermatozoa. Theriogenology, California, v. 68, n. 1, p. 204-212, 2007.

MILIORINI, A. B.; MURGAS, L. D. S.; ROSA, P. V. A.; OBERLENDER, G.; PEREIRA, G. J. M.; COSTA, D. V. Morphological classification proposal for curimba (Prochilodus lineatus) sperm damages after cryopreservation. Aquaculture Research, Oxford, v. 42, n. 1, p. 177-187, 2011.

MOORE, J. C.; BERLOW, E. L.; COLEMAN, D. C. Detritus, trophic dynamics, and biodiversity. Ecology Letters, Oxford, v. 7, n. 1, p. 584-600, 2004.

NASCIMENTO, M. M.; NASCIMENTO, W. S.; CHELLAPA, N. T.; CHELLAPA, S. Biologia reprodutiva do curimatã comum, Prochilodus brevis (Characiformes: Prochilodontidae) no açude Marechal Dutra, Rio Grande do Norte, Brasil. Biota Amazônica, Macapá, v. 2, n. 2, p. 31-43, 2012.

NAVARRO, R. D.; NAVARRO, F. K. S. P.; FELIZARDO, V. O.; MURGAS, L. D. S.; ANDRADE, S. S. Semen quality of Curimba (Prochilodus lineatus) cryopreserved with vitamins. Acta Scientiarum, Maringá, v. 36, n. 1, p. 55-60, 2014.

NUNES, L. T.; OLIVEIRA, M. S.; LOPES, J. T.; SOUZA, M. E. M.; PINHEIRO, R. R. R.; CAMPELLO, C. C.; SALMITO-VANDERLEY, C. S. B. Cryopreservation of Prochilodus brevis semen: freezing media and thawing rates. Semina: Ciências Agrárias, Londrina, v. 37, n. 3, p. 1643-1654, 2016.

OLIVEIRA, M. S.; ALMEIDA-MONTEIRO, P. S.; NUNES, L. T.; LINHARES, F. R. A.; PINHEIRO, J. P. S.; PINHEIRO, R. R. R.; FERREIRA, F. O.; CAMPELLO, C. C.; SALMITO-VANDERLEY, C. S. B. Cryopreservation of tambaqui semen using programmed freezing machine and dry shipper. Semina: Ciências Agrárias, Londrina, v. 37, n. 4, p. 2167-2180, 2016.
PAULA, D. A. J.; ANDRADE, S. S.; MURGAS, L. D. S.; FELIZARDO, V. O.; WINKALER, E. U.; ZEVIANI, W.; FREITAS, R. T. F. Vitamin E and reduced glutathione in Prochilodus lineatus (curimba) sêmen cryopreservation (Characiformes: Prochilodontidae). Neotropical Ichthyology, Porto Alegre, v. 10, n. 3, p. 661-665, 2012.

PENA, F. J.; JOHANNISSON, A.; WALLGREN, M.; RODRIGUEZ-MARTINEZ, H. Antioxidant supplementation in vitro improves boar sperm motility and mitochondrial membrane potential after cryopreservation of different fractions of the ejaculate. Animal Reproduction Science, Amsterdam, v. 78, n. 1, p. 85-98, 2003.

PEÑARANDA, D. S.; PÉREZ, L.; GALLEGO, V.; JOVER, M.; ASTURIANO, J. F. Improvement of European cel sperm cryopreservation method by preventing spermatozoa movement activation caused by cryoprotectants. Cryobiology, Nova Iorque, v. 59, n. 1, p. 119-126, 2009.

PINHEIRO, J. P. S.; MELO-MACIEL, M. A. P.; LINHARES, F. R. A.; LOPES, J. T.; ALMEIDA, P. S.; PINHEIRO, R. R. R.; TORRES, T. M.; SALMITOVANDERLEY, C. S. B. Use of glucose or BTSTM associated with DMSO or methylglycol under two different freezing protocols for the cryopreservation of sperm from the common curimatã (Prochilodus brevis). Animal Reproduction, Belo Horizonte, v. 13, n. 4, p. 779786, 2016.

PURDY, P. H. A review on goat sperm cryopreservation. Small Ruminant Research, Amsterdam, v. 63, n. 1, p. 215-225, 2006.

SALMITO-VANDERLEY, C. S. B.; VIEIRA, M. J. A. F.; LEITE, L. V.; OLIVEIRA, F. C. E.; LINHARES, F. R. A.; SAlGUEIRO, C. C. M.; NUNES, J. F. Meios de congelação para conservação de sêmen de peixes da família Characidae. Ciência Animal, Fortaleza, v. 22, n. 1, p. 255-268, 2012.

SARLÓS, P.; MOLNÁR, A.; KÓKAI, M.; GÁBOR, G.; RÁTKY, J. Comparative evaluation of the effect of antioxidants in the conservation of ram semen. Acta Veterinaria Hungarica, Budapeste, v. 50, n. 2, p. 235245, 2002.

SHIMODA, E. Análise e criopreservação do sêmen da piabanha Brycon insignis Steindachner, 1877 (Pisces, Characidae). 2004. Tese (Doutorado em Produção Animal) - Universidade Estadual do Norte Fluminense Darcy Ribeiro, Campos dos Goytacazes.

SIKKA, S. C. Oxidative stress and role of antioxidants in normal and abnormal sperm function. Frontiers in Bioscience, Irvine, v. 1, n. 1, p. 78-86, 1996. 
Role of oxidative stress and antioxidants in andrology and assisted reproductive technology. Journal of Andrology, Malden, v. 25, n. 1, p. 5-18, 2004.

SILVA, E. C. B.; GUERRA, M. M. P. Terapias antioxidantes na criopreservação espermática. Revista Portuguesa de Ciências Veterinárias, Lisboa, v. 107, n. 1, p. 143-149, 2012.

SOLIS-MURGAS, L. D.; FELIZARDO, V. O.; FERREIRA, M. R.; ANDRADE, E. S.; VERAS, G. C. Importância da avaliação dos parâmetros reprodutivos em peixes nativos. Revista Brasileira de Reprodução Animal, Belo Horizonte, v. 35, n. 1, p. 186-191, 2011.

STORNELLI, M. C.; TITTARELLI, C. M.; SAVIGNONE, C. A.; STORNELLI, M. A. Efecto de los procesos de criopreservación sobre la fertilidad seminal. Analecta Veterinaria, Buenos Aires, v. 25, n. 2, p. 28-35, 2005.
UBILLA, A.; VALDEBENITO, I. Use of antioxidants on rainbow trout Oncorhynchus mykiss (Walbaum, 1792) sperm diluent: effects on motility and fertilizing capability. Latim American Journal of Aquatic Research, Valparaiso, v. 39, n. 1, p. 338-343, 2011.

VASCONCELOS, S. M. L.; GOULART, M. O. F.; MOURA, J. B. F.; MANFREDINI, V.; BENFATO, M. S.; KUBOTA, L. T. Espécies reativas de oxigênio e de nitrogênio, antioxidantes e marcadores de dano oxidativo em sangue humano: principais métodos analíticos para sua determinação. Química Nova, São Paulo, v. 30, n. 5, p. 1323-1338, 2007.

WATSON, P. F. The causes of reduced fertility with cryopreserved semen. Animal Reproduction Science, Amsterdam, v. 60, n. 61, p. 481-492, 2000. 
